\title{
Mineral requirements of growing horses
}

\author{
H. F. Hintz \\ Department of Animal Science, Cornell University, Ithaca NY, USA
}

\begin{abstract}
Summary
The mineral requirements of weanlings have received some attention in recent years, but much more work is needed. Calcium is of concern because of its need for bone formation but also because excessive amounts can decrease utilization of other minerals. The calcium to phosphorus ratio must also be considered. A range of ratios of 1:1 to 3:1 seems to be reasonable. The National Research Council (NRC, 1989) suggested that growing horses, 4 to 12 months old with a mature weight of $500 \mathrm{~kg}$, would need 29-36 g of calcium daily. Some authors have suggested that NRC calcium values are too low whereas some have suggested NRC are too high. It is concluded that at this time there is not sufficient evidence to significantly change the NRC calcium requirements.

The biggest range in recommendations is probably for copper and zinc. The NRC (1989) recommended dietary concentrations of 10 and $40 \mathrm{mg} / \mathrm{kg}$ of dry matter, respectively. Others have suggested that much higher copper and zinc concentrations are needed to prevent osteochondrosis. Reasons for differences among experimental results need to be determined.
\end{abstract}

Keywords: $\quad$ minerals, horses, calcium, phosphorus, copper

\section{Mineralstoffbedarf von wachsenden Fohlen}

Seit einigen Jahren wird dem Mineralstoffbedarf von Aufzuchtfohlen vermehrt Beachtung geschenkt - dennoch bleibt auf diesem Gebiet noch einiges zu tun.

Von Bedeutung ist hier vor allem der Calciumbedarf in Hinsicht auf den Knochenaufbau, wobei berücksichtigt werden muß, daß eine exzessive Zufuhr von Calcium zu verminderter Utilisation anderer Mineralstoffe führen kann. Das Ca/Phosphor-Verhältnis sollte zwischen 1:1 bis 1:3 liegen. Das National Research Council (NRC,1989) empfiehlt, daß Pferde mit einem angestrebten Endgewicht von $500 \mathrm{~kg}$ in der Wachstumsphase im Alter von 4 bis 12 Monaten täglich 29-36 g Calcium erhalten. Es liegen Arbeiten anderer Autoren vor, die die vom NRC empfohlenen Mengenangaben entweder als zu niedrig oder aber als zu hoch bezeichnen. Zum jetzigen Zeitpunkt liegen jedoch keine ausreichenden Ergebnisse vor, die eine Änderung der derzeitigen Empfehlungen des NRC hinsichtlich des Mineralstoffbedarfs von Fohlen rechtfertigen.

Die größte Spanne der Empfehlungen besteht wahrscheinlich im Bereich des Kupfer- und Zinkbedarfs. Während das NRC (1989) Konzentrationen von $10 \mathrm{bzw} .40 \mathrm{mg} / \mathrm{kg}$ Trockenmasse im Futter als ausreichend ansieht, werden nach Aussagen anderer Autoren wesentlich höhere Kupfer- und Zinkkonzentrationen benöigt, um Osteochondrosis vorzubeugen.

Hier gilt es, mögliche Ursachen zu finden, die zu den unterschiedlichen Versuchsergebnissen geführt haben.

Schlüsselwörter: Mineralien, Pferde, Kalzium, Phosphor, Kupfer

Horses require at least 15 minerals. A few of these 15 minerals have been studied in reasonable detail but most have received little attention. Furthermore, there are probably other minerals that are required but have not been recognized as essential. Thus, there is much to do. Mineral deficiencies are certainly not uncommon and have been of great detriment to horses. Reading some of the many case histories of big head disease or osteoporosis that were published in the 1800's and early 1900's not only provides a perspective of the importance of the mineral adequacy but also brings the realization of how severe and traumatic many of the treatments for big head were before the role of calcium was finally realized. For example, Cole (1847) suggested that „a chisel about two inches wide should be heated in a fire until red hot". The chisel was to be applied to the affected horse's head midway between the eye and nostril and pressed to burn „entirely into the bone." Spring (1858) suggested that the skull of a horse with big head should be punctured with an awl and arsenic poured into the opening or „a concoction of roots of rattle weed (one peck boiled down with three pounds of bacon) be driven into the skull with a hot iron every day for a week."

We are now appalled at such barbaric treatments and wonder how such an obvious remedy as dietary calcium was not recognized sooner. According to McCay (1973), the first direct experiment in which dietary calcium was shown to modify the composition of bone was by Chossat in 1842 . He fed pigeons wheat or wheat plus calcium. The pigeons fed wheat had very fragile bones whereas those fed the wheat plus calcium had normal bones. But lime or calcium supplementation was not routinely recommended for the treatment of big head disease until the latter part of the nineteenth century. It is likely that in the future as more becomes known about trace minerals, some may wonder why we did not recognize the importance of certain minerals in 1996.

\section{Calcium and Phosphorus}

I have been fascinated by mineral nutrition of horses ever since I observed the dramatic effects of calcium phosphorus 
imbalance on the skeleton of the horses in the experiments conducted by Krook and Lowe (1964). The horses were 5 to 9 months of age at the start of the experiment and were fed diets containing $0.23 \% \mathrm{Ca}$ and $0.86 \% \mathrm{P}$. An insidious shifting lameness was observed by 12 weeks. There was subsequently some enlargement of the jawbones.

Savage et al. (1993) also studied the effect of calcium phosphorus imbalance on bone development in growing horses. They fed diets containing $0.57 \% \mathrm{Ca}$ and $0.44 \% \mathrm{P}$ or $0.57 \%$ $\mathrm{Ca}$ and $1.71 \% \mathrm{P}$ (dry matter basis) to foals 4.5 to 6.5 months of age. The excess phosphorus induced clinical and histological changes suggestive of dyschondroplasia in 5 of 6 foals. Two of 12 foals fed the control diet had histological changes but none of the foals fed the control diet had clinical or radiological changes.

The above experiments demonstrate that excess phosphorus can induce calcium deficiency. They do not establish the minimum requirement for calcium but suggest that a dietary concentration of $0.57 \%$ calcium would be adequate for growing foals if excess phosphorus is not present.

Ott and Asquith (1989) reported that increasing the calcium and phosphorus dietary concentration from $0.46 \%$ and 0.36 $\%$, respectively to $0.70 \%$ and $0.48 \%$, respectively did not increase bone mineralization in yearling horses. The lower concentrations provided about $35 \mathrm{~g}$ of calcium and $21 \mathrm{~g}$ of phosphorus daily.

Thompson et al. (1988) fed diets containing 0.70\%, 0.45\% or $0.20 \%$ calcium to foals that had been weaned at 130 days of age. The diets were fed until the foals were 370 days of age. The low calcium diet decreased radiographic bone density and third metacarpal length. No differences were seen between the foals fed $0.45 \%$ or $0.70 \%$ calcium.

Cymbaluk et al. (1989) suggested that endogenous phosphorus losses of the growing horse may be greater than those used in the calculations of NRC (1989) requirement for phosphorus. It was also suggested that excessive calcium intake may have a greater effect on phosphorus utilization than previously reported. Horses at 24 months of age were in negative phosphorus balance even though intake exceeded NRC (1989) recommendations. Cymbaluk and Christison (1989a), however, found that increasing the phosphorus concentration in the diet of horses growing in cold climates from $0.24 \%$ to $0.68 \%$ or $0.98 \%$ did not increase rate of gain. Furthermore, phosphorus intakes that were marginally deficient when compared to NRC standards did not alter productivity, feed intake, or occurrence of musculoskeletal abnormalities in weanling horses (Cymbaluk and Christison (1989b).

NRC (1989) suggested that diets for foals 4 to 6 months of age should contain $0.56 \%$ to $0.68 \%$ calcium. In order to compare recommendations it might be better to express requirements in grams per day. NRC (1989) concluded that horses 4 to 12 months of age with an expected mature weight of $500 \mathrm{~kg}$ need 29 to $36 \mathrm{~g}$ of calcium per day. The variation depends on the rate of growth. INRA (1990) suggested 28 to $39 \mathrm{~g}$ of calcium per day for horses 8 to 12 months of age (mature weight of $500 \mathrm{~kg}$ ). Recommendations from Germany were 28 to $33 \mathrm{~g}$ per day (extrapolated from tables for 400 and $600 \mathrm{~kg}$ animals), (Meyer et al., 1994). NRC (1989) recommended 16 to $20 \mathrm{~g}$ of phosphorus daily for the above horses. INRA (1990) recommended 16 to $22 \mathrm{~g}$ of phosphorus per day. Meyer et al. (1994) recommended 18 to $23 \mathrm{~g}$ daily.

There has been significant concern about the dangers of excessive calcium. There is no doubt that excess calcium can be harmful. Large excesses of any nutrient can be toxic. The question has been what level is considered harmful. Krook and Maylin (1988) suggested that excessive dietary calcium could cause hypercalcitonism which would inhibit calcium reabsorption and replacement of cartilage by bone. Furthermore, it was suggested that the NRC requirements were high enough to induce nutritional hypercalcitonism with manifestations of osteochondrosis and osteopetrosis. However, Thompson et al. (1988) reported no adverse effects in bone density or bone growth in weanlings fed diets containing $2.50 \%$ calcium, a level several times that recommended by NRC (1989).

Savage et al. (1993) reported that diets containing $1.95 \%$ calcium fed to weanlings did not increase the incidence of dyschondroplasia. In contrast to the suggestions of Krook and Maylin (1988), Gabel (1987) suggested that survey data indicated that NRC (1989) recommendations should be higher.

Although there is no doubt that further studies on the effects of calcium and phosphorus nutrition on the development of skeletal problems could be rewarding, I think there is little evidence at this time to suggest that the NRC (1989) requirements for calcium and phosphorus of growing horses should be significantly changed. Further studies of the effect of dietary cation-anion balance (DCAB) on calcium metabolism and skeletal problems could be fruitful. DCAB has been shown to influence the incidence of tibial dyschondroplasia in chickens (Edwards, 1984) a condition with some similarities to osteochondrosis in foals. Studies with growing horses demonstrate that DCAB can influence calcium metabolism and excretion (Wall et al., 1992; Copper et al., 1995).

Although inadequate calcium intake is more common than inadequate phosphorus intake, the possibility of phosphorus deficiency in foals cannot be ignored, particularly when they are consuming diets containing primarily hay (Greiwe-Crandell et al., 1993).

\section{Copper and Zinc}

These trace minerals have received a great amount of attention ever since Knight et al. (1985) reported a negative correlation between the copper concentrations in the diets of weanlings and incidence of skeletal problems in a survey of horse farms. There is no doubt that copper deficiency can induce skeletal problems. Bridges and Harris (1988) produced osteochondrosis experimentally in foals fed a diet containing $1.7 \mathrm{mg}$ of copper per $\mathrm{kg}$ of feed. Hurting et al. (1993) fed foals diets containing 8 or 25 ppm copper. They concluded there was a relationship between low copper intake in fast growing horses and inferior collagen quality, bio- 
mechanically weak cartilage and osteochondrosis lesions. All nine foals fed the low copper diet had histological lesions but only 5 developed clinical lesions. It was concluded that factors other than nutrition, such as individual variation in growth or genetic potential influence the expression of osteochondrosis.

Asai et al. (1993) reported that a survey of 25 farms in Japan. Eleven percent of foals had severe and $15 \%$ had moderate epiphysitis of the fetlock joint when the copper content of pasture grasses was about $50 \%$ of NRC requirement. But they pointed out that epiphysititis of the knee joint did not seem correlated with dietary copper.

There has been considerable discussion about the copper requirements of growing horses. In 1989, NRC considered that the data suggesting high levels of copper were inconclusive and decided not to increase the requirement but keep it at the concentration of $10 \mathrm{mg} / \mathrm{kg}$ of diet. Meyer (1994) recently reviewed copper nutrition in the horse. He suggested a requirement of 10-12 mg per $\mathrm{kg}$ of diet but he pointed out that attention should be paid to copper status of weaned foals grazing heath or moorland pastures containing low copper concentrations.

Pool (1995) reported that he had conducted post mortem examinations on many foals with developmental orthopedic disease and found very few foals with histological lesions consistent with copper deficiency.

Bridges and Moffitt (1990) reported that in their study that "it is apparent that $7.7 \mathrm{mg}$ of copper per $\mathrm{kg}$ in a diet is adequate to maintain normal copper metabolism in weanling foals."

Ott and Asquith (1989) reported that when the diet of yearling horses contained 7 ppm copper and 36 ppm zinc bone mineralization was decreased but when the diet contained 11 ppm copper and 40 ppm zinc, bone mineralization was not enhanced by further trace mineral supplementation. Ott and Asquith (1995) further reported that the addition of copper or copper and zinc to diets containing less than the NRC requirement did not increase bone mineral deposition in yearling horses.

On the other hand, many feel copper deficiency in foals to be fairly common and that NRC recommendations are not adequate. Asai et al. (1993) suggested NRC recommendations are too low for the prevention of epiphysitis in the fetlock joint because, in a survey, $13 \%$ of the foals fed $102 \%$ of NRC copper requirement had epiphysitis of the fetlock joint. Knight et al. (1990) suggested that copper requirement be increased because foal fed diets containing $55 \mathrm{mg}$ of copper per $\mathrm{kg}$ of diet had a lower incidence of skeletal lesions than foals fed $15 \mathrm{mg}$ of copper per kg of diet. Gabel et al. (1987) recommended that the total diet contain 25-30 mg of copper per kg. Hurtig et al. (1993) also recommended that the diets of growing horses contain 20-25 mg/kg copper. Cymbaluk and Smart (1993) suggested that copper can be added to supply $20-25 \mathrm{mg} / \mathrm{kg}$ total diet for susceptible breeds although there have been no conclusive factorial experiments that have confirmed these copper requirements. They also concluded that non-susceptible horses, ponies and draft horses probably need only 10 to $15 \mathrm{mg} / \mathrm{kg}$ of diet.
Cymbaluk and Smart (1993) point out that evaluating copper status in horses is an imprecise science. Perhaps requirements are increased by increased endogenous loss, increased needs for gain, breed specificity or reduced copper digestibility that influences requirements. The large differences in estimates of copper requirements clearly support the premise that many factors influence the requirement.

Zinc is often considered to be the most important cation inhibitor of copper absorption by horses (Cymbaluk and Smart, 1993). No dramatic effects of zinc on copper metabolism were found in two studies in which the diets contained as much as $500 \mathrm{mg}$ of zinc per kg of diet (Coger et al., 1987; Hoyt et al., 1995). Bridges and Moffitt (1990), however, reported that the addition of 1000 or $2000 \mathrm{mg}$ of zinc per $\mathrm{kg}$ of diet adversely affected copper metabolism in foals. It seems prudent to recommend that the $\mathrm{Zn}$ : Cu ratio should not be wider than $4: 1$ to $5: 1$ (Cymbaluk and Smart, 1993).

Although molybdenum reduces copper availability in ruminants, intakes up to $107 \mathrm{mg}$ of molybdenum per $\mathrm{kg}$ of feed had little impact on copper metabolism in horses (Cymbaluk et al., 1981; Strickland et al., 1987).

As mentioned above, further studies are needed to develop better indicators of copper status. The recent work of Meyer and Tiegs (1995) is encouraging. They reported liver copper concentrations in the fetal and neonate. Livers of 75 aborted fetuses $\left(6^{\text {th }}-11^{\text {th }}\right.$ month of gestation) and 19 neonates (1-2 weeks of age) were analyzed. It was suggested that the liver copper concentrations of 10- and 11-month-old fetuses and those of newborn foals could be used to evaluate copper status of mares. Values of $300 \mu \mathrm{g} \mathrm{Cu} / \mathrm{g}$ in liver (dry matter basis) of fetuses and at least $400 \mu \mathrm{g} \mathrm{Cu} / \mathrm{g}$ in liver (dry matter basis) of newborns were suggested to indicate copper intake and absorption by the mare.

\section{Other minerals}

The requirements for trace minerals have received little attention. Several of the NRC (1989) estimates are based on studies with other species. A comparison of the requirements by NRC (1989) and Meyer et al. (1994) are shown in table 1. There is reasonable agreement between the two groups but, of course, that does not prove accuracy. Meyer et al. (1994) recommended 4 to $6 \mathrm{~g}$ of magnesium per day for foals with a mature weight of $500 \mathrm{~kg}$, slightly higher than the 3.7 to $4.3 \mathrm{~g}$ of magnesium recommended by NRC.

Tab. 1: Comparison of requirements for trace minerals.

: Vergleich der Versorgungsempfehlungen für Spurenelemente

\begin{tabular}{|llc|}
\hline & Meyer et al., 1994 & NRC (1989) \\
\hline \multicolumn{3}{c|}{$\mathrm{mg} / \mathrm{kg}$ of diet (dry matter) } \\
Iron & $80-100$ & 50 \\
Copper & $10-12$ & 10 \\
Zinc & 50 & 40 \\
Manganese & 40 & 40 \\
Selenium & $0.15-0.2$ & 0.2 \\
lodine & $0.1-0.2$ & 0.1 \\
\hline
\end{tabular}




\section{References}

Asai, Y., Mizuno, Y., Yamamoto, O. and Fujikawa, H. (1993): Requirements of copper and zinc for foals in connection with the incidence of epiphysitis. Animal Science and Technology, Japan, 64, 1193-1200.

Bridges, C. H. and Harris, E. D. (1988): Cartilaginous fractures ("osteochondritis dissecans") induced experimentally in foals with low copper diets. J. Am. Vet. Med. Assoc., 193, 215-221.

Bridges, C. H. and Moffitt, P. G. (1990): Influence of variable content of dietary zinc on copper metabolism of weanling foals. Am. J. Vet. Res., 51, 275-280.

Coger, L. S., Hintz, H. F., Schryver, H. F. and Lowe, J. E. (1987): The effect of high zinc intake on copper metabolism and bone development in growing ponies. Proc. Equine Nutr. Physiol. Soc., 173-176.

Cole, S. W. (1847): The American Veterinarian. John Jewett and Co., Boston, Mass., pp. 143

Copper, S. R., Kline, K. H., Foreman, J. H., Brady, H. A., Frey, L. P. and Sennello, K. A. (1995): Effects of dietary cation-anion balance on blood $\mathrm{pH}$, acid-base parameters, serum and urine mineral levels and parathyroid hormone in weanling horses. J. Equine Vet. Sci. 15, 417-420.

Cymbaluk, N. F. and Christison, G. I. (1989 a): Effects of dietary energy and phosphorus content on blood chemistry and development of growing horses. J. Anim. Sci., 67, 951-958.

Cymbaluk, N. F. and Christison, G. I. (1989 b): Effects of diet and climate on growing horses. J. Anim. Sci., 67, 49-59.

Cymbaluk, N. F., Christison, G. I. and Leach, D. H. (1989): Nutrient utilization by limit-and ad libitum-fed growing horses. J. Anim. Sci., 67, 414-425.

Cymbaluk, N. F., Schryver, H. F., Hintz, H. F., Smith, D. F. and Lowe, J. E. (1981): Influence of dietary molybdenum on copper metabolism in ponies. J. Nutr., 111, 96-106.

Cymbaluk, N. F. and Smart, M. E. (1993): A review of possible metabolic relationships of copper to equine bone disease. Equine Vet. J., Supplement 16, 19-26.

Edwards, H. M., Jr. (1984): Studies on the etiology of tibial dyschondroplasia in chickens. J. Nutr. 114, 1001-1013.

Gabel, A. A., Knight, D. A., Reed, S. M., Pultz, J. A., Powers, J. D., Bramlage, L. R. and Tyznik, W. J. (1987): Comparison of incidence and severity of developmental orthopedic disease on 17 farms before and after adjustment of ration. 33 Proc. Amer. Assoc. Equine Pract., 163-170.

Greiwe-Crandell, K. M., Kronfeld, D. D., Morrow, G. A. and Tiegs, W. (1993): Phosphorus and selenium depletion in Thoroughbred mares and weanlings. Prod. 13th Equine Nutrition Physiol Symposium, 39-41.

Hoyt, J. K, Potter, G. D., Greenead, L. W. and Anderson, J. G. (1995): Copper balance in miniature horses fed varying amounts of zinc. J. Eq. Vet. Sci 15, 357-359.

Hurtig, M., Green, S., Dobson, H., Mikuni-Takagaki, Y. and Choi, J. (1993): Correlative study of defective cartilage and bone growth in foals fed a low-copper diet. Equine Vet. J., Supplement 16, 66-73.

INRA (1990): L'alminentation des chevaux. W. Martin-Rosset, ed., Paris, $277 \mathrm{pp}$.
Knight, D. A., Gabel, A. A., Reed, S. M., Embertson, R. M., Tyznik, W. J. and Bramlage, L. R. (1985): Correlation of dietary mineral to incidence and severity of metabolic bone disease in Ohio and Kentucky. Proc. Am. Assoc. Equine Practitioners, 445-461.

Knight, D. A., Weisbrode, S. E., Schmall, L. M., Reed, S. M., Gabel, A. A Bramlage, I. R. and Tyznik, W. I. (1990): The effects of copper supplementation on the prevalence of cartilage lesions in foals. Equine Vet. J. 22, 426-432

Krook, L. and Lowe, J. E. (1964): Nutritional secondary hyperparathyroidism in the horse. Pathol. Vet, Supplement 1, 1, 1-98.

Krook, L. and Maylin, G. (1988): Fractures in Thoroughbred racehorses. Cornell Vet, Supplement 1, 78, 5-133

McCay, C. M. (1973): Notes on the history of nutrition research. Hans Huber Publ., Berne, pp. 172

Meyer, H. (1994): Cu-Stoffwechsel und-Bedarf des Pferdes. Übers. Tierernährg, 22, 363-394

Meyer, H., Kirchgessner, M., Bronsch, K., Freese, H.-H., Jeroch, H., Pallauf, J., Pfeffer, E. and Schulz, E. (1994): Energie- und Nährstoffbedarf landwirtschaftlicher Nutztiere. Empfehlungen zur Energie- und Nährstoffversorgung der Pferde, p. 48.

Meyer, $H$. and Tiegs, $W$. (1995): Liver copper concentration in the fetus and newly born foal. Proc. 14th Equine Nutrition and Physiology Symp, 8-12.

National Research Council (1989): Nutrient requirements of horses. 5th Edition NRC-NAS, Washington, DC.

Ott, E. A. and Asquith, R. L. (1989): The influence of mineral supplementation on growth and skeletal development of yearling horses. J. Anim. Sci. 67, 2831-2840.

Ott, E. A. and Asquith, R. L. (1995): Trace mineral supplementation of year ling horses. J. Anim. Sci. 73, 466-471.

Pool, R. R. (1995): Nutritional insignificance as it relates to developmental orthopedic dissease. Proc. 14th Equine Nutrition and Physiology Sympo sium, 344-352.

Savage, C. J., McCarthy, R. M. and Jeffcott, L. B. (1993): Effects of dietary phosphorus and calcium on induction of dyschondroplasia in foals. Equine Vet. J. Supplement 16, 74-79.

Spring, S. (1858): Big head in horses. The Cultivator, 6, 15.

Strickland, K., Smith, F., Wood, M. and Mason, J. (1987): Dietary molybdenum as a putative copper antagonist in the horse. Eq. Vet. J., 19, 50-54.

Thompson, K. N., Jackson, S. G. and Baker, J. P. (1988): The influence of high planes of nutrition and skeletal development on skeletal growth and development of weanling horses. J. Anim. Sci. 66, 2459-2467.

Wall, D. L., Topliff, D. R., Freeman, D. W., Wagner, D. G. and Breazile, J. E. (1992): Effects of dietary cation-anion balance on urinary mineral excretion in exercised horses. J. Equine Vet Sci. 12, 168-170.

\section{H. F. Hintz}

Department of Animal Science

Cornell University

Ithaca NY 14853-4801 USA 